\title{
ECONOMIC IMPACT OF CUKUROVA UNIVERSITY ON ADANA
}

\author{
Can MAVRUK ${ }^{1}$ \\ Ersin KIRAL ${ }^{2}$ \\ Gülsen KIRAL ${ }^{3}$
}

\begin{abstract}
This study calculates local economic and employment impact of Cukurova University for 2015-2016 fiscal year using Keynesian multiplier method. For that, university budget expenditures data, national statistical data resources and survey data were used. Economic impact of the university is measured by demand side expenditure. Keynesian income multiplier was calculated to be 1,23. Marginal propensity to consume, a key factor in estimating economic impact, was estimated to be 0,61 using ordinary least squares method in Eviews. This paper shows economic importance of the University to locality by estimating total local income and employment, and that the University makes a significant contribution to local economy. Total direct and total indirect impact are estimated to be $€ 284$ and $€ 689$ million respectively. Total local impact of the University was estimated to be $€ 1,2$ billion with an additional income of $€ 227$ million and additional employment of 6874 .
\end{abstract}

Keywords: Economic impact, university expenditure

Jel Classification: 018,043

\section{ÇUKUROVA ÜNIVERSITESININ ADANA EKONOMISINE KATKISI}

Öz

Bu çalışma Çukurova Üniversitesinin 2015-2016 dönemi için yerel ekonomik ve istihdam katkısını Keynesyen çarpan yöntemi ile hesaplamaktadır. Bu amaçla, üniversitenin bütçe harcamaları verisi, ulusal istatistiksel veri kaynakları ve anket verileri kullanılmıştır. Üniversitenin ekonomik katkısı talep yanlı harcama ile ölçülmüştür. Keynesyen gelir çarpanı 1,23 bulunmuştur. Ekonomik katkıyı hesaplamada önemli bir faktör olan marjinal tüketim eğilimi, E-views istatistik paket programında sıradan en küçük kareler yöntemi kullanılarak 0,61 hesaplanmıştır. Bu makale, toplam yerel gelir ve istihdamı hesaplamakla üniversitesinin bulunduğu yerel bölge için ekonomik önemini ve üniversitenin yerel ekonomiye katkıda önemli bir güç olduğunu göstermektedir. Toplam doğrudan ve toplam dolaylı katkı sırasıyla Ł284 ve €689 milyon hesaplanmıştır. Ł227 milyon ek gelir ve 6874 ek istihdam kapasitesine sahip olan üniversitenin toplam yerel katkısı Ł1,2 milyar hesaplanmıştır.

Anahtar Kelimeler: Ekonomik katkı, Üniversite harcamaları

Jel Sınıflandırması: O18, 043

\footnotetext{
${ }^{1}$ Ögrr. Gör. Ömer Halisdemir Üniversitesi NSBMYO can.mavruk@faculty.umuc.edu

${ }^{2}$ Yrd. Doç. Dr. Çukurova Üniversitesi iiiiBF Ekonometri ekiral@cu.edu.tr

${ }^{3}$ Doç Dr. Çukurova Üniversitesi iiiBF Ekonometri gkiral@cu.edu.tr
} 


\section{Introduction}

Economic impact of universities can be measured by demand side expenditure (short run effect) and knowledge and human capital based (long run effect) contributions. Armstrong and Taylor (2000) included local business (demand for services), local government (services and revenues, improved revenue base, additional demand) and local households (increase in household income and spending) in short run impact and human capital (graduates, skill level of local workforce, new firm formation), attractiveness of local economy (inword migration of capital, inward migration of skilled labor) and knowledge (R\&D) in long run impact. According to Martin (1998) there are two main approaches for measuring the economic impact of university activities: (i) the static approach which is based upon simulations through an input-output (I-O) model or a crude regional multiplier, and (ii) the dynamic approach which corresponds to the share of university research in the real increase in gross domestic product (GDP) imputable to the generation of knowledge (technology). To put forth economic effects, the most commonly used methods are collected in five separate groups (Gorkemli, 2009:172): 1) Econometric model (Booth et al., 1976: 566-575; Caffrey et al.,1971:31); 2) Economic base model (Cook,1970:146-153); 3) Input-Output Model (Bonner, 1968:339-343; Dorsett et al., 1982:419-428); 4) Cost benefit analysis (Hansen et al., 1969:177-186) and 5) Keynesian Multiplier Model (Brownrigg, 1973:281-290; Moore, 1979:334-342; Armstrong, 1993:1660-1668). A vast number of articles can be found in the literature on the expenditure based economic contributions of the universities. However, the study of human capital and knowledge based economic impact requires a student tracking system and information about R\&D. Long run economic impact studies are performed in developed countries such as US and UK.

Our study will focus on Keynesian multiplier model. According to the literature of economic impact of universities, it is expected that Keynesian expenditure mult/plier be between 1 and 2 . More developed the region of the university is closer to 2 the multipler will be. Researchers in Turkey have to calculate such a multiplier for their studies because it is not provided by Turkish national data resources.

Migration of industrial production from Adana to Istanbul has dramatically declined economic contribution to Adana. Migration of production triggers migration of university graduates and therefore negatively effects human capital contribution of the University. Local companies' shift to high value added goods and services (HVAGS) and cooperation with Cukurova University (CU) would keep the graduates in the locality. As a matter of fact, $\mathrm{CU}$ and Adana companies have a potential for this shift such as making passenger cars. CU, already ranked fourth in the nation, intends to increase the number of industrial thesis projects (CU, 2014). The Engineering students have already produced an electric car. If Temsa, a global bus and light truck manufacturer company, opens a production line for passenger cars, it will make a tremendous contribution to local economy and the nation. Participation of the university in industrial research and development of HVAGS will not only increase economic activity in the region, but it will also give an opportunity to employment of human capital. In turn, long run economic contribution of the University makes sense.

State universities rely on state budget grants provided for personnel, goods and services and capital expenditures in every fiscal year. An increase in state budget grant contributes to development of state universities in Turkey and increases economic activities in local economy such as new employment, construction of schools, private dorms and apartments, banks, shopping centers, gas stations etc. As for $\mathrm{CU}$, activities include increasing number of international and domestic students on campus, connection of metro line from city center to campus, construction of schools of Pharmacy and Fine Arts, Oncology Hospital, shopping center, welness and sports center and new roads (CU 2014-2018 Strategic Plan, 2014). These continuing activities increase the number of university personnel and students and therefore increase university expenditure, 
personnel and student expenditure on goods and services in the locality and generate more income in local economy.

This study will focus on the University expenditure based contribution. These expenditures include direct tax, indirect tax and marginal propensity to consume. The objective of this article is to estimate local economic impact of CU using Keynesian multiplier method. For that, gross local output (GLO) and local disposable income (LDI) with respect to employment are estimated.

In this study local or locality means Seyhan, Cukurova and Sarıcam districts. University main campus is located at Sarıcam district. Vocational School of Adana is located at Cukurova district. Most students and personnel reside in these three districts.

The remaining of the article is organized as follows: literature summary in the second section, data and method in the third section, findings in the fourth section, conclusion in the fifth section.

\section{Literature Summary}

Erkekoğlu (2000); estimated direct economic impact to be $€ 4,6$ million, direct employment impact 2171 jobs, indirect economic impact $€ 10,8$ million and indirect employment impact 2794 jobs.

Ohme (2003); based on regional I-O Modeling System (RIMS II), applied a multiplier of 1,8 created by US Bureau of Economic Analysis to the direct expenditure (student, faculty, staff and university expenditures) of the University of Delaware and total economic impact was estimated to be $\$ 735$ million. According to the Bureau of Economic Analysis, approximately 20 jobs are generated for each additional $\$ 1$ million of output. The estimated spending from students, faculty, staff, and the University therefore support approximately 8,170 jobs in the state of Delaware.

Tugcu (2004); estimated marginal propensity to consume to be 0,668463 and expenditure multiplier to be 3,01 by expenditure multiplier formula.

Garrido-Yserte and Gallo-Rivera (2007); used Ryan's short cut model to estimate direct and indirect impact of the University of Alcala upon the local economy. Direct economic impact was estimated to be 118 million euros and indirect economic impact was estimated to be 99 million euros. Total economic impact was estimated 217 million euros by using income multiplier 1,84. Number of full time jobs was estimated to be 3839 .

Tavoletti (2007); estimated local economic and employment impact of Cardiff University. Keynesian income multiplier was 1,14 , total local income $£ 147$ million in Cardiff and $£ 153$ million in South East Wales as a whole in the 2000-2001 period, LDI $£ 80$ million in Cardiff and $£ 83$ million in South East Wales, 652 indirect additional jobs in Cardiff and 59 in the rest of South East Wales generated by 2,962 direct employees.

Sürmeli (2008); estimated personnel mean propensity to consume of 0,9498. Direct effects were estimated to be $€ 188$ million and direct employment effect was 4776 jobs, indirect effects Ł254 million and indirect employment effect was 2162, and induced effects were $€ 564$ million.

Görkemli (2009); estimated marginal propensity to consume to be 0,67 and expenditure multiplier 3,06 by using expenditure multiplier formula $1 /(1-c)$. Direct effects were estimated $€ 41$ million and direct employment effect was 4205 jobs, indirect effects were $€ 238$ million and indirect employment effect was 9497 jobs, and induced effects were $€ 853$ million and employment effect was 34085 jobs.

Sudmant (2009); estimated expenditure multiplier to be 1,50, direct impact 1,25 billion, indirect impact 576 million and induced impact 2,74 billion dollars for the University of the British Columbia.

Ceyhan and Güney (2011); followed Cooke and Huggins (1997) and estimated marginal propensity to consume to be 0,53 , GLO 3,77 and LDI 3,50, direct impact $€ 12$ million, direct 
employment 329 jobs, indirect impact Ł16,1 million and indirect employment 457 jobs for Bartın University.

Sen (2011); used Huggins and Cooke (1997) model and estimated marginal propensity to consume to be 0,65 and expenditure multiplier 1,59 . The author calculated total GLO to be $€ 56$ million and total LDI to be $€ 34$ million.

Mavruk et al. (2014); estimated marginal propensity to consume to be 0,70 and Keynesian income multiplier 1,22. The authors calculated direct, indirect and induced impact to be $€ 56$ million, $€ 223$ million and $€ 320$ million respectively. They also calculated total employment effect of Nigde (Omer Halisdemir) University to be 5163.

\section{Data Set ve Method}

Expenditure base Keynesian method is applied to estimate total local economic impact. Together with student and visitor spendings in the locality the university expenditures constitutes a series of expenditures for short time period which may take more than one year. After first injection of expenditures by the university, this amount of 636rogr circulates in the locality for a finite number of rounds and generates a cumulative output which is greater than the initial injection. Each round generates a local output and income in the locality. Since expenditures in the locality include tax which is paid back to the state in each round, tax is deducted in each round until local output and income both become zero. Finally the sum of outputs is considered to be total economic impact. Besides, the ratio of the sum to the first round expenditures is considered to be GLO multiplier which includes Keynesian multiplier. The same can be said 636rogram sum of LDIs.

In this method, university resources and national data were supported by survey data. Direct impact was calculated using CU 2015-2016 fiscal year budget expenditures. Student, personnel and their visitors expenditure data from surveys were used to calculate indirect impact. To calculate induced impact the sum of direct and indirect impact was multiplied by Keynesian income multiplier. Marginal propensity to consume is estimated using OLS method in E-Views. GDP and Final Consumption Expenditure of Resident Households 1998Q1-2016Q2 data extracted from Turkish Statistics Institute (TUIK) Database is used to estimate marginal propensity to consume. To estimate indirect employment, service production was divided by the number of employment in service sector for which data is retrieved from TUIK. To estimate indirect impact of the University, 1851 students and 276 university personnel were surveyed. A 34 question survey was handed out by surveyors to 1851 randomly selected students at randomly selected locations of the University. In the first part of the survey demographical questions and in the second part of the survey student income and expenditure questions were asked. When entering data for gender, female $=0$ and male=1. SPSS 17 and E-views 9 statistical 636rogramsa re used in data analysis. Expenditures made by personnel and students only in the province of Adana have been included in the scope.

Lineer regression model is $X_{t}=b+c Y_{t}$ where

$X_{t}=$ Share of private final consumption expenditures of households (PFCEH) in GDP (TL)

$Y_{t}=$ Value of GDP (TL)

$c=$ Marginal propensity to consume

$b=$ Autonom consumption expenditure

Short run model is

$$
\Delta \mathrm{X}_{\mathrm{t}}=\mathrm{b}+\mathrm{c} \Delta \mathrm{Y}_{\mathrm{t}}+\mathrm{d}^{*} \mathrm{u}_{\mathrm{t}-1}
$$

from which coefficients are estimated using 1998:Q1-2016:Q2 PFCEH and GDP data obtained from TUIK web site.

Keynesian income multiplier is 


$$
\mathrm{k}=1 /[1-\operatorname{cw}(1-\mathrm{t})(1-\mathrm{i})]
$$

where $w$ : rate of personnel expenditure in the locality, $t$ : direct tax rate, $i$ : indirect tax rate $\mathrm{c}=\Delta \mathrm{X} / \Delta \mathrm{Y}$ (change in consumption for every $€ 1$ increase in national income) where $\Delta \mathrm{X}$ : change in consumption and $\Delta \mathrm{Y}$ : change in national income.

Total local impact of the University was estimated by adding GLO and local employment impact was estimated by multiplying local expenses related to the University by employment factor.

For every round GLO is calculated by the following formula:

$$
Y_{n}= \begin{cases}L+A+d C+h G & n=1 \\ v S+V+w c D_{1} & n=2 \\ w c D_{n-1} & n \geq 3\end{cases}
$$
University, dC is proportion of construction (immovable) expenditures in the locality, $h \mathrm{G}$ is proportion of goods and services in the locality, $\mathrm{S}$ is student expenditure, $\mathrm{v}$ is proportion of student expenditures in the locality, $w$ is proportion of personnel net income expenditure in the locality and $\mathrm{V}$ is visitors expenditure.

For every round LDI is calculated by the following formula:

$$
D_{n}= \begin{cases}(1-t)\left(Y_{1}-i h G\right) & n=1 \\ (1-t)(1-i) Y_{n} & n \geq 2\end{cases}
$$

where t: direct tax rate, $\mathrm{i}$ : indirect tax rate, $\mathrm{h}$ : proportion of goods and services expenditure in locality and $Y_{n}$ is local output at round $n$.

Keynesian factor for LDI is calculated by

$$
\begin{aligned}
& \frac{D_{f}}{D_{1}}=\frac{\sum D_{i}}{D_{1}}=\frac{D_{1}+D_{2}+D_{3}+\ldots}{D_{1}}=\frac{D_{1}+D_{2}+(1-t)(1-i) Y_{3}+(1-t)(1-i) Y_{4}+\ldots}{D_{1}} \\
& =\frac{D_{1}+D_{2}+(1-t)(1-i) w c D_{2}+(1-t)(1-i) w c(1-t)(1-i) w c D_{2}+\ldots}{D_{1}} \\
& =1+\frac{D_{2}\left[1+w c(1-t)(1-i)+(w c(1-t)(1-i))^{2}+\ldots\right]}{D_{1}}= \\
& 1+\frac{D_{2}}{D_{1}}\left(\frac{1}{1-w c(1-t)(1-i)}\right)=1+\frac{D_{2}}{D_{1}} k
\end{aligned}
$$

$|w c(1-t)(1-i)|<1$ and $1 /[1-w c(1-t)(1-i)]$ is Keynesian income multiplier.

where

Keynesian factor for GLO is calculated by

$$
\begin{aligned}
& \frac{Y_{f}}{Y_{1}}=\frac{\sum Y_{i}}{Y_{1}}=\frac{Y_{1}+Y_{2}+Y_{3}+\ldots}{Y_{1}}=\frac{Y_{1}+Y_{2}+w c(1-t)(1-i) Y_{2}+w c(1-t)(1-i) w c(1-t)(1-i) Y_{2}+\ldots}{Y_{1}} \\
& =\frac{Y_{1}+Y_{2}\left[1+w c(1-t)(1-i)+(w c(1-t)(1-i))^{2}+\ldots\right]}{Y_{1}}=1+\frac{Y_{2}}{Y_{1}}\left(\frac{1}{1-w c(1-t)(1-i)}\right) \\
& =1+\frac{Y_{2}}{Y_{1}} k
\end{aligned}
$$

\section{Findings}

Cross-tabulating gender and age in SPSS 18 we found that of 1851 surveyed students, $50 \%$ was female and $50 \%$ was male. The number of surveyed students with respect to their schools is given in Table 1. 
Table 1: The Number of Surveyed Students With Respect To Their Schools

\begin{tabular}{lccccc}
\hline School & Frequency & School & Frequency & School & Frequency \\
\hline Medicine & 83 & Pharmacy & 7 & Fine Arts & 12 \\
Economic and & 637 & Law & 83 & Adana & 21 \\
Science and Literature & 178 & Health Services & 19 & Foreign & 3 \\
Engineering & 269 & Theology & 54 & Sports & 29 \\
Education & 130 & Communication & 50 & Dental & 16 \\
Agriculture & 231 & Health Sciences & 24 & Civil Aviation & 2 \\
State Conservatory & 3 & & & & \\
\hline
\end{tabular}

\subsection{Direct Impact}

Academic personnel income $(L)$, goods and services $(G)$ and immovable or construction costs (C) all provide a significant rate of the University expenditures and are included in direct impact to local economy. Table 2 shows CU 2016 fiscal year budget expenditures (も) which are extracted from (CU 2016 Activity Report, 2016).

Table 2: CU 2016 Budget Expenditures

\begin{tabular}{lrr}
\hline Economic code & \multicolumn{1}{c}{ Spent } & Percent \\
\hline Personnel expenditures & $272,110,972$ & 60,1 \\
Social security expenditures & $45,578,003$ & 10,0 \\
Goods and services & $51,101,354$ & 11,3 \\
Current transfers & $11,061,623$ & 2,4 \\
Capital expenditures & $73,249,266$ & 16,2 \\
\hline
\end{tabular}

We consider the mean personnel income including development benefit to be $€ 5,000$ not including extra pays. Based on personnel survey, mean personnel expenditure is $€ 3,092$ in the locality. Personnel expenditure in the locality is calculated by

$\mathrm{wL}$

Most of the university personnel resides in the locality, but only $61,84 \%$ of personnel expenditures is spent in the locality: $272,110,972 * 0,6184=€ 168,273,425$.

Goods and services expenditures spent in the locality is calculated by

hG

According to CU Strategy Development Office, $75 \%$ of goods and services expenditures is spent in the locality. Substitution in (8) gives $51,101,354 * 75 \%=€ 38,326,016.61 \%$ of capital expenditures is immovable expenditures: $73,249,266 * 0,61=€ 44,682,052$.

The proportion of construction expenses and major repair, alteration or improvement expenses to immovable costs is calculated by

$\mathrm{dC}$

where $d$ is rate of immovable cost and $\mathrm{C}$ is immovable cost in the locality. About $85 \%$ of immovable costs is occured in the locality. So $85 \%$ of immovable costs in the locality is

$€ 44,682,052 * 0.85=€ 37,979,744$ from (9). Subtracting purchased manufactured goods from capital expenditures gives

$$
\mathrm{C}_{\mathrm{e}}-(1-\mathrm{d}) \mathrm{C}
$$

where $C_{e}$ is the capital expenditure. Substitution in (10) gives $73,249,266-44,682,052 * 0,15=$ $€ 66,546,958$. We consider that this amount is spent in the locality.

Therefore, total direct impact (TDI) to local economy is calculated by 
$\mathrm{TDI}=\mathrm{wL}+\mathrm{hG}+\mathrm{C}_{\mathrm{e}}-(1-\mathrm{d}) \mathrm{C}+\mathrm{T}_{\mathrm{c}}$

where $T_{c}$ is current transfers. Substitution in (11) gives $T D I=168,273,425+38,326,016$ $+66,546,958+11,061,623=€ 284,208,022$.

\subsection{Indirect Impact}

Total indirect impact is the sum of expenditures of students (S), visitors (V) and personnel income from outside the university (A).

\subsubsection{Student Expenditure}

It was estimated that 1851 students came to Adana from the other cities and stayed nine months during 2015-2016 academic year which includes Fall and Spring terms for a total of 32 weeks.

Table 3: Mean Monthly Expenditures of The Surveyed Students

\begin{tabular}{ccccccc}
\hline & Cafe-canteen & Health & Transportation & Personal & Housing & Food-drink \\
\hline Mean & 161 & 48 & 214 & 134 & 189 & 191 \\
\hline & Clothing & Social activity & Energy & Communication & Education & \\
\hline Mean & 154 & 88 & 40 & 49 & 61 & \\
\hline
\end{tabular}

Table 3 shows that mean monthly expenditure of surveyed students including housing is 1,329 and mean monthly expenditure not including housing is 1,140 . Housing share in monthly expenditure is $14,3 \%$, which is significantly different from $29,4 \%$ calculated by (Dilek et al., 2016).

We consider that mean stay time in Adana is 9 months. Economic impact of students is calculated by

$\mathrm{S}=\left(\right.$ mean monthly expenditure not including housing*months +housing cost*months)* $\mathrm{n}_{\mathrm{s}}$ (12)

where $n_{s}$ is the number of students in the defined locality and $\mathrm{S}$ is total economic impact of students.

Economic impact of 1851 surveyed students is calculated from (12) to be $(1140 * 9+189 * 12) * 1851=€ 23,189,328$. Generalizing this to a total of 38797 students gives an estimate of total student expenditure to be $S=(1140 * 9+189 * 12) * 38797=€ 486,048,816$ from (10).

The rate of student spending in the locality is calculated from

$V=1-$ (spending rate outside the locality)

Mean monthly expenditure in the locality is $€ 916$. Spending rate outside the locality is $(1,140-916) / 1,140=0,20$. Therefore, $v=0,80$ from (13). Weighted mean annual expenditures of students is $(875 * 12 * 1140+976 * 9 * 1329) / 1851=23,643,936 / 1851=€ 12,774$.

\subsubsection{Visitor Expenditure}

The mean number of students' visitors from other cities is 4,65 persons per year, mean number of days stayed 6,53 per year and mean expenditure per day is $€ 221,51$. Economic impact of students' visitors is calculated as $V_{s}=4,65 * 6,53 * 221,51 * 38797 * 0,55=€ 143,522,604$. According to survey results $55 \%$ of students is not from Adana. Visitor expenditure for students from Adana is not included in our calculation. Mean spending in enrollment day is 271 and in graduation ceremony day is 250 . The total number of students graduated except associate and vocational schools is 5767 . Economic impact of enrollment and graduation is

$\mathrm{V}_{\text {eg }}=(271+250) * 5767 * 0,55=€ 1,652,534$.

Table 4: Mean Number of Student Visitors and Mean Number of Days Per Visit

\begin{tabular}{lccc}
\hline Surveyed students & $\mathrm{N}$ & Average number of visitors & Mean number of days per visit \\
\hline From Adana & 875 & 6,04 & 8,58
\end{tabular}




\begin{tabular}{lccc} 
From other cities & 976 & 3,38 & 4,69 \\
All & 1851 & 4,64 & 6,53 \\
\hline
\end{tabular}

In addition, economic impact of visitors of the University personnel is calculated. Surveyed 242 personnel had a total of 1572 visitors with mean number of visitors 5,78 per academic year, mean number of days stayed 6,15 per academic year and mean expenditure $€ 208,89$ per day. Therefore, generalizing to 2500 staff and 1886 academic personnel, the economic impact of visitors is $\mathrm{V}_{\mathrm{p}}=5,78 * 6,15 * 208,89 * 4386=€ 32,567,860$.

Total economic impact of visitors is calculated by

$$
\mathrm{V}=\mathrm{V}_{\mathrm{s}}+\mathrm{V}_{\mathrm{eg}}+\mathrm{V}_{\mathrm{p}}
$$

Substitution in (14) gives $V=143,522,604+1,652,534+32,567,860=€ 177,742,998$

Based on personnel survey, mean monthly personnel income outside the University is $€ 465$. Personnel additional income was estimated to be $9,3 \%$ of personnel income which is $0,093 * 272,110,972=€ 25,306,320$

Total indirect impact (TII) is the sum of student expenditures, visitor expenditures and personnel income from outside the University:

$$
\mathrm{TII}=\mathrm{S}+\mathrm{V}+\mathrm{A}
$$

Substitution in (15) gives TII $=486,048,816+177,742,998+25,306,320=€ 689,098,134$

\subsection{Induced Impact}

"A proportion of local sales to the University employee are paid out as wages to local employees and profits to local employers/business owners, and a proportion of this income is in turn re-spent on local goods and services". (Lantz et al.2002, p.11).

Base expenditure (E) is personnel (labor, employee) income (L) plus goods and services expenditure $(G)$ :

$$
\mathrm{E}=\mathrm{L}+\mathrm{G}
$$

Substitution in (16) gives $E=272,110,972+51,101,354=€ 323,212,326$

First round GLO $Y_{1}$ includes labor income, personnel income from outside the University, proportion of construction (immovable) expenditures in the locality, proportion of goods and services in the locality.

"What should be counted as new first-round economic activity is tuition, room and board, and other spending by students who alternatively would not have attended a local institution, and revenues from students from inside the area who, in contrast, would have instead attended a college elsewhere (import substitution). Non-student expenditures attracted to the area by the particular college or university" (Siegfried et al., 2006:14).

In this study, tuition was excluded from student expenses. As a state university CU has been fully supported by the government budget which is from outside the locality. Therefore, the budget expenditure of the University can be considered to be new to the locality except social security expenditures which is paid back to the government. Capital expenditure of the University is included in the University budget. Immovable expenses are included in and takes large portion of capital expenditures. Proportion of immovable expenses in the locality was $€ 37,979,744$. According to the University resources, the proportion of goods and services expenditures in the locality is $\mathrm{hG}$ $=0,75 * 51,101,354=€ 38,326,016$. Additional income rate of the University personnel was estimated from personnel survey to be 0,093 or $9,3 \%$. We substitute all of the above values in the first round GLO formula (3):

$Y 1=272,110,972+(0,093)(272,110,972)+37,979,744+0,75 * 51,101,354=373,723,052$. 


\subsubsection{Direct and Indirect Tax Effect}

How direct tax (t) and indirect tax (i) are taken affects Keynesian multiplier and total economic impact to be estimated. Highest indirect tax rates are ET(Excise Duty Tax) $130 \%$, Special Communication Tax (SCT) 25\% and VAT (Value Added Tax) \%18. Special communication tax share in total tax revenue was 1,4\%. According to Revenue Administration, in 2016 some commonly consumed products to which excise duty tax rates applied are cigarettes and tobacco $69 \%$, beer $63,3 \%$, rakı $81 \%$, wine and vodka $86 \%$, whiskey $107 \%$, cola soda pops $25 \%$, mobile phones $20 \%$. Excise duty tax share in total tax revenues is $27 \%$. Indirect tax charged to a household electricity bill was 45\%, to a cell phone subscription bill was 48\%. According to Minister of Finance, in 2016 indirect tax share and direct tax share in total tax revenues were $64 \%$ and $36 \%$, respectively. So $t=0,36$ is used for direct tax effect in our estimation.

Based on student survey, for mean spending percentages on cafe-canteen, housing, health, travel, food and drink, clothing, social activities, energy, communication, books and personal spendings, the indirect tax rate (i) is estimated by

$$
\mathrm{i}_{\mathrm{s}}=\sum(\text { share of expenditure item in total expenditure }) *(\text { tax rate })
$$

where $\sum$ shows the sum of the products. Calculations and substitutions in (17) gives $\mathrm{i}_{\mathrm{s}}=0,121[(0,18+0,08) / 2]+0,142(0,15)+0,036(0,08)+0,161(0,18)+0,144[(0,65+0,633+0,81+$ $0,86+1,07+0,18+0,08) / 7]+0,116(0,08)+0,066(0,08)+0,03(0,45)+0,037(0,48)+0,046[(0,08$ $+0,18) / 2]+0,101[(0,18+0,20) / 2]=0,228$.

Table 5: Mean Monthly Expenditures of The Surveyed Personnel

\begin{tabular}{ccccccc}
\hline & Services & Health & Transportation & Furniture and & Housing & Food-drink \\
\hline Mean & 163,54 & 109,23 & 408,69 & 510,25 & 565,54 & 661,38 \\
\hline Clothing & $\begin{array}{c}\text { Social } \\
\text { Activity }\end{array}$ & Energy & Communication & Education & Restaurant \\
\hline Mean & 479,78 & 199,05 & 249,74 & 108,29 & 277,21 & 249,60 \\
\hline
\end{tabular}

Based on personnel survey, mean monthly expenditure is 3982,30 and $46 \%$ of surveyed personnel does not own a car. Using the survey data on consumption expenditure of university personnel, indirect tax rate share was estimated to be $i_{p}=0,002+0,009+0,004+0,008+0,009+$ $0,012+0,028+0,006+0,022+0,148+0,021=0,263$.

Table 6: Indirect Tax Rates Paid By The University Personnel In 2015-2016 Academic Year

\begin{tabular}{lccc}
\hline Expenditure Items & $\begin{array}{c}\text { Expenditure } \\
\text { share }\end{array}$ & Indirect tax & \multicolumn{2}{c}{$\begin{array}{l}\text { Indirect tax rate } \\
\text { share }\end{array}$} \\
\hline Health & 0,027 & 0,08 & 0,002 \\
Education & 0,070 & 0,08 and 0,18 & 0,009 \\
Entertainment and cultural & 0,050 & 0,08 & 0,004 \\
Communication & 0,027 & $€ 47+0,25+0,05$ & 0,008 \\
Services & 0,050 & 0,18 & 0,009 \\
Shoe-Clothing & 0,145 & 0,08 & 0,012 \\
Furniture ve house appliences & 0,155 & 0,18 & 0,028 \\
Restaurant and hotel & 0,077 & 0,08 & 0,006 \\
Transportation & 0,124 & 0,18 & 0,022 \\
Food-drink-cigarettes-tobaco & 0,201 & $0,01,0,08,0,25,0,69,0,633$, & 0,148 \\
Housing & 0,142 & 0,15 & 0,021 \\
\hline
\end{tabular}

Student spending rate occured in the locality was $80 \% .80 \%$ of 38797 students is $n_{s}=$ $38797 * 0,80=31038$. From personnel survey, $61,84 \%$ of personnel spendings occured in the 
locality. $61,84 \%$ of 1851 personnel is $n_{p}=1851^{*} 0,6184=1145$. Weighted mean of indirect tax rates of students and personnel expenditures was estimated by

$$
\mathrm{i}=\left(\mathrm{n}_{\mathrm{s}} * \mathrm{i}_{\mathrm{s}}+\mathrm{n}_{\mathrm{p}} * \mathrm{i}_{\mathrm{p}}\right) /\left(\mathrm{n}_{\mathrm{s}}+\mathrm{n}_{\mathrm{p}}\right)
$$

Substitution in $(18)$ gives $i=[31038(0,228)+1145(0,263)] / 32183=0,23$ and 0,23 is used in the following rounds of income.

First round LDI from $(4)$ is D1 $=(1-0,36)(373,723,052-0,23 * 0,75 * 51,101,354)=€ 364,908,068$.

\subsubsection{Marginal Propensity To Consume}

Linear regression model is $X_{t}=b+c Y_{t}$ where $Y_{t}=G D P, X_{t}$ is the share of PFECH in GDP, $c=$ Marginal Propensity to Consume, $b=$ Autonom Consumption Expenditure. Calendar and seasonally adjusted data in short run model both was taken quarterly in number of periods between 1998Q1 and 2016Q2. There was no significant autocorrelation among the residuals. $X$ and $Y$ both increases as time increases. Time series $X$ and $Y$ do not have a constant mean and variance. Therefore, $X$ and $Y$ are not stationary, but they have a constant and trend. In our study to test the hypothesis whether $X$ and $Y$ have a unit root or not, ADF test is applied to both at level. ADF test values are found to be greater than McKinnon critical values. Therefore, $\mathrm{H}_{0}$ hypothesis could not be rejected which implies both $X$ and $Y$ series were not stationary at level. To make them stationary first difference was taken for each and ADF test values were found to be less than McKinnon critical values. Therefore, the first differenced series both $\Delta \mathrm{X}$ and $\Delta \mathrm{Y}$ became stationary.

Using OLS in E-Views 7, short run model is run to estimate marginal propensity to consume. From Table 7, short run model is $\Delta \mathrm{X}_{\mathrm{t}}=17,699+0,61 \Delta \mathrm{Y}_{\mathrm{t}}-0,24^{*} \mathrm{u}_{\mathrm{t}-1}$. Since the coefficient of error correction term $u_{t-1}$ was negative $\left(-1<u_{t-1}<0\right)$, it follows the economic theory (Sen, 2011). Short run coefficient of $\Delta \mathrm{Y}_{\mathrm{t}}$ is highly significant and is calculated to be 0,608 which is approximately 0,61 .

Table 7: Short Run Model

\begin{tabular}{lccll}
\hline \multicolumn{4}{l}{ Dependent Variable: $\mathrm{X}$} & \\
\hline Variable & Coefficient & Probability & & \\
\hline C & 17699.45 & 0,5829 & Prob(F-statistic) & 0,000000 \\
GDP & 0,607852 & 0,0000 & Durbin-Watson & 2,216666 \\
U(-1) & $-0,238309$ & 0,0039 & Adjusted R-squared & 0,555611 \\
& & & Akaike info criterion & 27,70568 \\
\hline
\end{tabular}

The share of final consumption expenditure of resident households in GDP is 59,5\% in 2016. Turkey's growth is mainly based on consumption and construction in recent years.

\subsubsection{Rounds of Other Outputs and Incomes}

Second round GLO includes student expenditure from (6), proportion of student expenditures in the locality, $\mathrm{w}$ is proportion of personnel net income expenditure in the locality and visitors expenditure. Now, we iteratively calculate GLO from (3) and LDI from (4):

2nd round GLO: Y2 = 0.80*486,048,816 + 177,742,998 +0,6184*0,61*364,908,068 = Ł704,234,132

2nd round LDI: D2 = $(1-t)(1-\mathrm{i}) \mathrm{Y} 2=(1-0,36)(1-0,23) * 704,234,132=€ 347,046,580$

3rd round GLO: $Y 3=w C D 2=0,6184 * 0,61 * 347,046,580=€ 130,914,299$

3rd round LDI: D3 $=(1-\mathrm{t})(1-\mathrm{i}) \mathrm{Y3}=(1-0,36) *(1-0,23) * 130,914,299=€ 64,514,567$

4th round GLO: Y4 $=\mathrm{wCD} 3=0,6184 * 0,61 * 64,514,567=24,336,443$

4th round LDI: D4 $=(1-\mathrm{t})(1-\mathrm{i}) \mathrm{Y} 4=(1-0,36)(1-0,23) * 24,336,443=11,992,999$

5th round GLO: Y5 = wCD4 = 0,6184*0,61*11,992,999 = 4,542,047

5 th round LDI: D5 $=(1-\mathrm{t})(1-\mathrm{i}) \mathrm{Y5}=(1-0,36)(1-0,23) * 4,542,047=2,229,450$

6th round GLO: Y6 $=$ wCD5 $=0,6184 * 0,61 * 2,229,450=841,002$

6th round LDI: D6 $=(1-\mathrm{t})(1-\mathrm{i}) \mathrm{Y6}=(1-0,36)(1-0,23) * 841,002=414,446$

7th round GLO: Y7 $=w C D 6=0,6184^{*} 0,61 * 414,446=156,339$ 
7th round LDI: D7 $=(1-\mathrm{t})(1-\mathrm{i}) \mathrm{Y7}=(1-0,36)(1-0,23) * 156,339=77,043$

8th round GLO: Y8 $=w C D 7=0,6184 * 0,61 * 77,043=29,063$

8th round LDI: D8 $=(1-\mathrm{t})(1-\mathrm{i}) \mathrm{Y} 8=(1-0,36)(1-0,23) * 29,063=14,322$

9th round GLO: Y9 = wCD8 $=0,6184 * 0,61 * 14,322=5,403$

9th round LDI: D9 $=(1-t)(1-\mathrm{i}) \mathrm{Y9}=(1-0,36)(1-0,23) * 5403=2,662$

10th round GLO: Y10 = wCD9 = 0,6184*0,61*2,662 = 1,004

10th round LDI: D10 $=(1-\mathrm{t})(1-\mathrm{i}) \mathrm{Y9}=(1-0,36)(1-0,23) * 1004=495$

11th round GLO: $Y 11=w C D 10=0,6184 * 0,61 * 495=187$

11th round LDI: D11 $=(1-\mathrm{t})(1-\mathrm{i}) \mathrm{Y} 10=(1-0,36)(1-0,23) * 187=92$

12th round GLO: Y12 = wCD10 $=0,6184 * 0,61 * 92=35$

12th round LDI: D12 $=(1-\mathrm{t})(1-\mathrm{i}) \mathrm{Y} 10=(1-0,36)(1-0,23) * 35=17$

13th round GLO: Y12 = $w C D 10=0,6184 * 0,61 * 17=6$

13th round LDI: D12 $=(1-\mathrm{t})(1-\mathrm{i}) \mathrm{Y} 10=(1-0,36)(1-0,23) * 6=3$

14th round GLO: Y12 = wCD10 $=0,6184 * 0,61 * 3=1$

14th round LDI: D12 $=(1-t)(1-\mathrm{i}) Y 10=(1-0,36)(1-0,23) * 1=0$

Table 8: GLO and LDI Estimated For 2015-2016 Fiscal Year

\begin{tabular}{lccccccc}
\hline Rounds & 1 & 2 & 3 & 4 & 5 & 6 & 7 \\
\hline$Y_{n}$ & $373,723,052$ & $704,234,132$ & $130,914,299$ & $24,336,443$ & $4,542,047$ & 841,002 & 156,339 \\
$D_{n}$ & $364,908,068$ & $347,046,580$ & $64,514,567$ & $11,992,999$ & $2,229,450$ & 414,446 & 77,043 \\
\hline Rounds & 8 & 9 & 10 & 11 & 12 & 13 & 14 \\
\hline$Y_{n}$ & 29,063 & 5,403 & 1,004 & 187 & 35 & 6 & 1 \\
$D_{n}$ & 14,322 & 2,662 & 495 & 92 & 17 & 3 & 0 \\
\hline
\end{tabular}

Total GLO: The sum of all GLOs from round 1 to round 14 gives the total GLO generated by CU in 2016:

$$
Y_{f}=\sum_{n=1}^{14} Y_{n}
$$

which is $€ 1,238,783,013$. As shown in Table 8, CU with its administration, staff, students and visitor expenditures in the locality would generate a total local income of $€ 1,24$ billion.

Total LDI: The sum of all LDIs from round 1 to round 14 gives the total LDI generated by CU in 2016:

$$
D_{f}=\sum_{n=1}^{14} D_{n}
$$

which is $€ 791,200,744$. The university has the effect of generating $€ 791$ million LDI in the locality.

Keynesian Factor for Local Output is $Y_{f} / Y_{1}=1+(704234132 / 373723052)[1 /(1-0,6184(0,61)(1-$ $0,36)(1-0,23)]=1+1,88 * 1,23=3,31$ from $(6)$.

Keynesian Factor for $L D I$ is $D_{f} / D_{1}=1+(68703 / 64184) * 1,23=2,17$ from (5).

"After literature review of estimated expenditure multipliers related to US and UK universities, GLO multiplier was observed to be changing between 1,5 and 3,5 and LDI multiplier between 1,15 and 3,15" (Sürmeli, 2008: 76). In this study, GLO Expenditure Base Factor: $\mathrm{Y}_{f} / \mathrm{E}=$ $1238783013 / 323212326=3,83$ and LDI Expenditure Base Factor: $D_{f} / E=791200744 /$ $323212326=2,45$. Every $€ 1$ initially injected to local economy generates $€ 3,83$ GLO and $€ 2,45$ LDI.

Keynesian income factor is $k=1 /[1-0,62(0,61)(1-0,36)(1-0,23)]=1,23$ from (2). We can interpret this result as "for every $€ 1$ spent in local economy, €0,23 additional gross income is generated".

Direct impact is the sum of the proportion of personnel expenditure occurs in locality and the proportion of goods, services, capital and transfer expenditures which occurs in locality. Total direct impact is $168,273,425+38,326,016+66,546,958+11,061,623=€ 284,208,022$. 
From student and personnel surveys student expenditure was estimated to be $€ 486,048,816$, personnel additional income was estimated to be $9,3 \%$ of personnel income which is $0,093 * 272,110,972=€ 25,306,320$ and total visitor expenditure was estimated to be $€ 177,742,998$.

Indirect impact is the sum of student expenditures, personnel additional income and visitor expenditures. Total Indirect impact $=486,048,816+177,742,998+25,306,320=€ 689,098,134$

Induced impact equals to the sum of direct and indirect impacts subtracted from total economic impact. Total Induced impact $=1,238,783,013-(284,208,022+689,098,134)=€ 223,860,416$. Total impact is the total GLO.

Table 9 summarizes all estimations of economic impacts and gives induced impact based on Keynesian income multiplier.

Table 9: University Expenditure Based Direct, Indirect and Induced Impact on Locality

\begin{tabular}{lr}
\hline 1.Direct Impact (a+b) & $284,208,022$ \\
a.Personnel expenditure $272,110,972 * 0,6184$ & $168,273,425$ \\
b.Goods, Services, Capital and Transfer Expenditures & $15,934,597$ \\
2.Indirect Impact (c+d+e) & $89,098,134$ \\
c. Personnel additional income $0,093 * 272,110,972$ & $25,306,320$ \\
d. Student expenditure $(1140 * 9+189 * 12) * 38797$ & $486,048,816$ \\
e. Visitor expenditure $143,522,604+1,652,534+32,567,860$ & $177,742,998$ \\
f. Keynesian factor & 1,23 \\
3.Induced Impact $\quad(1+2) * f$ & $1,197,166,572$ \\
\hline
\end{tabular}

According to TUIK, 2016 GDP in current prices is $\$ 856,8$ billion and population of Turkey is 79,8 million. Therefore, GDP per capita is $\$ 10,737$ in 2016 . Adana GDP share in total GDP of 2016 is $2 \%$ which is $\$ 17,1$ billion. Adana GDP per capita is estimated by dividing GDP of Adana by total population of Adana: $\$ 17,1$ billion/2201670 $=\$ 7,783$. Since locality in this study was defined as Sarıçam, Cukurova and Seyhan with a total population of 1316662, GDP of the locality is estimated by $7,783 * 1316662=\$ 10,3$ billion. GLO of the University is $1,238,783,013 / 3,25=\$ 381,164,004$ where mean $\$ 1=€ 3,25$ in 2016 (T.R. Ministry of Development). GLO share in local GDP is estimated by GLO/Local GDP $=0,38 / \$ 10,3$ billion $=0,037$ or 3,7\%. Total student expenditure share in local GDP is $\$ 0,15$ billion/ $\$ 10,3$ billion $=0,015$ or $1,5 \%$. Employee expenditure share in local GDP is 0,052 / $10,3=0,005$ or $0,5 \%$.

\subsection{Employment Impact}

Total employment impact was estimated from the sum of direct and indirect employment impact.

\subsubsection{Direct Employment Impact}

The University has provided 4806 full time jobs for personnel and staff in 2015- 2016 academic year.

\subsubsection{Indirect Employment Impact}

According to TUIK, 2014 GDP of Adana at current prices is $€ 41$ billion of which $€ 21$ billion $(50,2 \%)$ is services share. According to TUIK, 2014 GDP of Turkey at current prices is $€ 2,044$ trillion of which 1,1 trillion (54\%) is services share. According to TUIK, 2014 employment in services sector is 13,3 million persons. This number was $50.5 \%$ of the total employment which is 26,4 million. According to these numbers service production per person was 1,1 trillion/13,3 million $=€ 82,707$ or $1 / 82707=0,000012$ jobs for every directly spent $€ 1$ or 12 jobs for every million $€$ spent. To estimate the number of jobs generated by the University, local expenses related to the University was multiplied by the number of jobs generated by every $€ 1$ spent in the locality and added to the number of university personnel. The total number of staff and academic personnel at CU was 4806 
in 2015-2016 academic year, the number of jobs generated by every $€ 1$ spent in the locality was 0,000012 and local expenses related to the University was $284,208,022+689,098,134=$ $€ 973,306,156$. Therefore, the number of jobs the University has the effect of generating would be $973,306,156 * 0.000012=11680$ as a result of university activities and the University can support $11680-4806=6874$ additional jobs.

\section{Conclusion}

Total local income generated by CU in the locality is 3,7\% of the local GDP. This shows that the University generates significant economic activity in the locality. Income multiplier effect of directly and indirectly a total of 973 million input over other personal expenditures and therefore over most sectors in the city is calculated. From expenditure based Keynesian method, total economic impact of the University to locality is calculated to be about $€ 1,20$ billion. Additional income and the number of additional employment the University has the effect of generating directly or indirectly as a result of university activities are $€ 227$ million and 6874 persons respectively.

Continuing activities in the locality will create additional direct employment and additional indirect employment with additional expenditures, therefore will make a substantial economic contribution to the university and hence to local economy. Especially completion of metro line from the city center to campus will increase visitor traffic and hence expenditures on campus.

Human capital impact of the University would not be estimated in this study since there is no considerable cooperation between the university and local firms. In addition, there was no data available about graduates' employment status. If existing local global companies open high value added production lines (e.g. technology or car production) and cooperate with $\mathrm{CU}$, then we can talk about human capital impact of the University.

For future studies, cooperation of the university with the municipality, Adana Chamber of Commerce and local firms is possible. Besides, perhaps with in-migration of new firms due to high costs in industrial regions, long run impact can be estimated.

Acknowledgement: This research was supported by Cukurova University (Scientific Research Project) SBA 2017-9109.

\section{References}

Armstrong, H. W. (1993). The Local Income and Employment Impact of Lancester University, Urban Studies, 30(10), 1653-1688.

Armstrong, H. and Taylor, J. (2000). Regional Economics and Policy (3rd edition), Oxford: Blackwell.

Bonner, E. R. (1968). The Economic Impact of A University On Its Local Community, Journal of the American Institute of Planners, 34, 339-343.

Booth, G. G. and Jarret, J. E. (1976). The Identification and Estimation of A University's Economic Impacts, Journal of Higher Education, 47, 565-576.

Brownrigg, M. (1973). The Regional Income Multipliers: An Attempt to Complete the Model, Scottish Journal of Political Economy, 18, 281-297.

Caffrey, J. and Isaacs, H. H. (1971). Estimating The Impact of A College or University On The Local Economy, Washington D.C: American Council On Education. ERIC ED 252100.

Ceyhan, M. S. and Güney, G. (2011). Bartın Üniversitesi'nin Bartın İli'nin Ekonomik Gelişimine 20 Yıllık Projeksiyonda Katkılarının Değerlendirilmesi, Fırat Üniversitesi Sosyal Bilimler Dergisi, 21(2), 183-207. 
$\begin{array}{lllll}\text { Cukurova University } & \text { 2014-2018 } & \text { Strategic } & \text { Plan. } & \text { (2014). }\end{array}$ http://sgdb.cu.edu.tr/tr/Belgeler/PlanProgramveRaporlar/CU20142018SP.pdf

Cukurova University $2016 \quad$ Activity Report.
http://sgdb.cu.edu.tr/tr/Belgeler/PlanProgramveRaporlar/CU2016FR.pdf

Dilek, Ö., Kızıltan A. and Bayrak, A. Z. (2016). Demografik Özellikler ile Gelir-Harcama İlişkisi, Balkan Journal of Social Sciences, 656-668.

Dorsett, R. A. and Weiler, W. C. (1982). The Impact of Instiution's Federal Research Grants On the Economy of Its States, Journal of Higher Education, 53, 419-428.

Erkekoğlu, H. (2000). Bölge Üniversitelerinin Yerel Ekonomiye Katkıları: Sivas Cumhuriyet Üniversitesi Örneği, Erciyes Üniversitesi I.i.B.F. Dergisi, 16, 203- 210.

Garrido-Yserte, R. and Gallo-Rivera, M. T. (2010). The Impact of the University Upon Local Economy: Three Methods To Estimate Demand-Side Effects, The Annals of Regional Science, 44(1), 39-67.

Görkemli, H. N. (2009). Selçuk Üniversitesi'nin Konya Kent Ekonomisine Etkileri, Selçuk Üniversitesi Sosyal Bilimler Enstitüsü Dergisi, 22, 169-186.

Hansen, W. L. and Weisbrod, B. A. (1969). The Distribution of Costs and Direct Benefits of Public Higher Education: The Case of California Institutions, The Journal of Human Resources, 4, 176-191.

Huggins, R. and Cooke, P. (1997). The Economic Impact of Cardiff University: Innovation, Learning and Job Generation, GeoJournal, 41(4), 325-337.

Johansen, T. and Arano, K. (2011). The Economic Impact of Fort Hays State University On the State of Kansas: Fiscal Year 2010, Kansas. https://www.fhsu.edu/uploadedFiles/executive/docking/reports/FHSU\%202010\%20Eco nomic\%20Impact\%20Final\%20Report.pdf

Lantz, V. A., Brander, J. R. G. and Yigezu, Y. A. (2002). The Economic Impact of The University of New Brunswick: Estimations and Comparisons with Other Canadian Universities, New Brunswick.

Martin, F. (1998). The Economic Impact of Canadian University R\&D, Research Policy, 27(7), 677687.

Moore G. A. (1979). Local Income Generation and Regional Income Redistribution In A System of Public Higher Education, Journal of Higher Education, 50, 334-348.

Ohme, A. M. (2003). The Economic Impact of A University On Its Community and State: Examining Trends Four Years Later, Delaware. http://www1.udel.edu/IR/presentations/EconImpact.doc

Sudmant, W. (2009). The Economic Impact of the University of British Columbia, Vancouver. https://president.ubc.ca/files/2013/02/economic_impact_2009.pdf

Sen, A. (2011). Local Income and Employment Impact of Universities: The Case of Izmir University of Economics, Journal of Applied Economics and Business Research, 1, 25-42.

Siegfried, J. J., Sanderson, A. R. and McHenry, P. (2007). The Economic Impact of Colleges and Universities, Economics of Education Review, 26, 546-58.

Sürmeli, F. (2008). Anadolu Üniversitesi'nin Eskişehir'e Etkileri ve Şehrin Üniversiteyi Algılayışı, Eskişehir: Anadolu Üniversitesi Yayınları. 
Tavoletti, E. (2007). Assessing the Regional Economic Impact of Higher Education Institutions: An application to The University of Cardiff, Transition Studies Review, 14(3), 507-522.

Tuğçu, C. T. (2004). Üniversitelerin Yerel Ekonomik Faaliyet Hacmine Katkıları: Nevşehir Örneği, Ekonomi Sempozyumu, 2, 61-80, Kayseri.

Turkish Ministry of Development.

http://www.mod.gov.tr/Lists/MainEconomicallndicators/Attachments/1446/25-

(2016). kurlar.xlsx 
